\title{
Cyklofiliny - białka o wielu funkcjach
}

\section{Przemysław Olejnik}

\section{Katarzyna Nuc ${ }^{\bowtie}$}

Uniwersytet Przyrodniczy w Poznaniu, Katedra Biochemii i Biotechnologii, Poznań

Uniwersytet Przyrodniczy w Poznaniu, Katedra Biochemii i Biotechnologii, ul. Dojazd 11, 60-632 Poznań; tel.: (61) 84660 49, e-mail: ktnuc@up.poznan.pl

Artykuł otrzymano 5 czerwca 2018 r. Artykuł zaakceptowano 15 czerwca 2018 r.

Słowa kluczowe: cyklofiliny, fałdowanie białek, izomerazy peptydyloprolilowe

\section{STRESZCZENIE}

A ktywne formy białek powstają $\mathrm{w}$ wyniku translacji oraz zmian zachodzących $\mathrm{w}$ trakA cie, bądź po tym procesie (fałdowanie, potranslacyjne modyfikacje, kierowanie do odpowiedniego przedziału komórkowego). Struktura przestrzenna białka uzależniona jest od jego sekwencji aminokwasowej co udowodnił Christian Anfinsen, który badając fałdowanie rybonukleazy A, skupił się na odzyskiwaniu aktywności zdenaturowanego enzymu w wyniku prowadzonego procesu renaturacji (nagroda Nobla $w$ dziedzinie chemii $w$ 1972 r. razem z Stanfordem Moore'em i Williamem H. Steinem). Fałdowanie polipeptydów stabilizowane jest i wspomagane przez dwie grupy białek, są to czaperony (nazywane również białkami opiekuńczymi) oraz izomerazy: disulfidoizomerazy (PDI, ang. protein disulfide isomerase, EC 5.3.4.1) i izomerazy peptydyloprolilowe (PPI, ang. peptidylprolyl isomerase EC 5.2.1.8). Czaperony asystują podczas fałdowania białek utrzymując ich stany przejściowe i zapobiegają tworzeniu nieprawidłowych struktur, natomiast izomerazy prowadzą izomeryzację wiązań dwusiarczkowych (PDI) i peptydyloprolilowych (PPI). Praca ta w całości poświęcona jest charakterystyce cyklofilin, należących do rodziny PPI ze szczególnym uwzględnieniem ich funkcji $w$ procesach związanych $z$ regulacją i patogenezą.

\section{IZOMERAZY PEPTYDYLOPROLILOWE}

Większość wiązań peptydowych w polipeptydach, występuje w konfiguracji trans. Taka konfiguracja jest energetycznie bardziej korzystna ze względu na ewentualną zawadę przestrzenną łańcuchów bocznych następujących po sobie reszt aminokwasowych. Wyjątek stanowi wiązanie peptydowe Xaa-Pro (Xaa oznacza dowolny aminokwas), które może występować zarówno w konfiguracji trans jak i cis. Różnica swobodnej energii między konfiguracją trans i cis dla układu Xaa-Pro wynosi zaledwie 0,5 kcal/mol, w przeciwieństwie do pozostałych wiązań peptydowych gdzie wynosi ona około 2,6 kcal/mol [1]. Konfigurację cis wiązania peptydowego Xaa-nonPro (gdzie nonPro oznacza, że nie jest to reszta proliny) stwierdzono w strukturze zaledwie 0,03\% białek i wykazano, że izomery te są ważne dla ich aktywności [2].

Niektóre izomerazy peptydyloprolilowe zaliczane są do rodziny białek określanych jako immunofiliny, czyli białek wpływających na proces odpowiedzi immunologicznej komórki. Jako immunofiliny klasyfikowane są: białka oddziałujące z FK506 czyli FKBP (ang. FK506 binding protein) i cyklofiliny, natomiast parwuliny, które również posiadają aktywność izomerazową nie wykazują właściwości immunosupresyjnej [3]. Wymienione powyżej białka różnią się pod względem struktury, a ich aktywność izomerazowa może być blokowana poprzez oddziaływanie ze specyficznymi związkami nazywanymi często immunosupresorami. Cyklofiliny są blokowane przez cyklosporynę A (CsA) białko FKBP przez FK506 (tacrolimus) lub rapamycynę, a parwuliny przez 5-hydroksy-1,4-naftochinon.

Zainteresowanie immunofilinami wzrosło przy okazji wyjaśniania procesów związanych z modulowaniem szlaków, kontrolujących zarówno proliferację, jak i apoptozę limfocytów T. Szlaki te związane są z aktywacją białek takich jak NFkB, NF-AT i Nur77, które są specyficznymi czynnikami transkrypcyjnymi a ich funkcjonalność kontrolowana jest przez kalcyneurynę. W sposób pośredni wymienione czynniki transkrypcyjne aktywują ekspresję określonych genów w limfocytach T w wyniku zewnątrzkomórkowej stymulacji. Szczególne zainteresowanie wzbudziła możliwość zablokowania aktywacji limfocytów T w odpowiedzi na przeprowadzony przeszczep. Wykazano, że kompleks CypA/CsA wpływa na proces aktywacji limfocytów T poprzez inaktywację kalcyneuryny blokując jej aktywność fosfatazy [4]. W konsekwencji niemożliwa jest defosforylacja, a co za tym idzie eksport do jądra cytoplazmatycznej podjednostki, specyficznego dla aktywnych limfocytów T, czynnika transkrypcyjnego NF-ATc regulującego ekspresję interleukiny IL-2. 
Izomeryzacja cis/trans wiązania peptydowego Xaa-Pro zachodzi bardzo wolno i podczas fałdowania białek jest etapem ograniczającym jego szybkość, np. zablokowanie aktywności izomerazowej cyklofiliny przez oddziaływanie z cyklosporyną A (CsA) znacznie opóźnia dojrzewanie kolagenu. Zakłada się, że około $10 \%$ wiązań Xaa-Pro w komórce może być w konfiguracji cis. Spontaniczna izomeryzacja tych wiązań jest powolna, jednakże proces ten może być przyspieszony (około 300 razy) przez izomerazy peptydyloprolilowe zarówno in vivo jak i in vitro. Enzymatyczne przyspieszenie fałdowania polipeptydów jest konieczne ze względu na możliwość włączenia przez komórkę, konkurencyjnych mechanizmów rozpoznających źle ufałdowane białka (np. kontrola jakości ufałdowania) co wiąże się z ich degradacją [5]. Wpływ występowania wiązań peptydowych Xaa-Pro zarówno w konfiguracji trans jak i cis, na czas fałdowania białek jest obserwowany nie tylko w przypadku krótkich polipeptydów ale również podczas renaturacji RNazy A, która posiada cztery reszty proliny $\mathrm{w}$ swojej strukturze. Dla białek posiadających w swojej strukturze pierwszorzędowej reszty proliny, ilość "stanów” przejściowych można określić wzorem $2^{\mathrm{n}}$, gdzie $n$ oznacza liczbę prolin [6]. Izomeryzacja cis-trans wiązania peptydowego Xaa-Pro, w pewnych przypadkach może regulować aktywność biologiczną ufałdowanych białek. Przykładami są: kinaza Itk (ang. interleukin-2 tyrosine kinase), biorąca udział w szlakach sygnałowych, prowadzących do aktywacji limfocytów T oraz domena CTD największej podjednostki polimerazy RNA II. Konformacyjna zmiana w domenie SH2 kinazy Itk, katalizowana przez cyklofilinę A (CypA), reguluje zdolność kinazy do rozpoznawania substratu, co $\mathrm{w}$ konsekwencji może prowadzić do zablokowania sygnału od receptora limfocytu T (TCR) [7]. Domena CTD największej podjednostki polimerazy RNA II, zbudowana jest z wielu powtórzeń siedmiu reszt aminokwasowych o sekwencji zgodnej YSPTSPS (u drożdży występuje 25 a u człowieka 52 powtórzeń). W zależności od fosforylacji odpowiednich reszt aminokwasowych (Ser, Thr i Tyr) oraz izomeryzacji wiązań peptydowych pomiędzy resztami proliny a poprzedzającymi je resztami seryny, kompleks powiązany z domeną CTD, oddziałuje z innymi białkami modulującymi kolejne etapy procesu transkrypcji.

Wśród białek prowadzących izomeryzację wiązań peptydowych Xaa-Pro, ważną grupę stanowią cyklofiliny. Ich cechą charakterystyczną jest obecność wysoce zachowawczej domeny CBD wiążącej cyklosporynę A (ang. çyclosporine $\mathrm{A}$ binding domain), zbudowanej z około 120 reszt aminokwasowych, która jest jednocześnie centrum aktywnym izomerazy. Struktura ta jest często określana jako domena cyklofilinowa.

Cyklofiliny występują w komórkach wszystkich badanych organizmów, a ich różne formy zostały zlokalizowane w cytoplazmie, jądrze komórkowym, mitochondriach, chloroplastach, retikulum endoplazmatycznym jak również $\mathrm{w}$ przestrzeni periplazmatycznej bakterii. Pomimo, że pierwotnie cyklofilinom przypisywano głównie rolę izomeraz działających podczas fałdowania białek, to obecnie coraz więcej informacji mamy na temat udziału różnych form cyklofilin w większych kompleksach białkowych, które wpływają pośrednio bądź bezpośrednio, na ekspresję genów zarówno na poziomie transkrypcji jak i translacji.

\section{ZNACZENIE CYKLOFILIN PODCZAS INFEKCJI WIRUSOWYCH}

Genomy wirusowe są mocno ograniczone ze względu na swoją objętość, co wynika z minimalizmu obciążenia i maksymalizacji wykorzystania. Dlatego strategia infekcji danego wirusa zakłada wykorzystywanie białek zainfekowanego gospodarza (bezpośrednio bądź po odpowiedniej modyfikacji) dla swoich celów związanych z infekcją a w konsekwencji namnażaniem własnego genomu.

Cyklofilina CypA człowieka pełni znaczącą rolę na wielu etapach podczas infekcji prowadzonej przez niektóre wirusy np. HIV-1 (ang. Human immunodeficiency virus), wirus grypy (ang. influenza A virus) czy żółtaczki typu B i C (HCV, ang. hepatitis C virus; HBV, Hepatitis B virus). Cyklofiliny często są włączane do otoczki białkowej wirusów w kompleksie z białkiem kapsydu (np. HIV, wirus grypy).

W latach dziewięćdziesiątych poprzedniego wieku Luban wraz ze współpracownikami, prowadzili badania nad identyfikacją białek które są istotne podczas infekcji wirusem HIV. Wirus HIV należy do rodzaju lentiwirusów z rodziny retrowirusów, którego genom stanowią dwie identyczne cząsteczki RNA. Stosując drożdżowy system dwuhybrydowy, badacze zidentyfikowali cyklofilinę CypA, jako białko oddziałujące z poliproteiną Gag kapsydu wirusa HIV-1 [8]. Dalsze badania pokazały, że CypA włączana jest do kapsydu wirusa, poprzez oddziaływanie z resztami aminokwasowymi Gly89 i Pro90 poliproteiny Gag [9]. Mutacja cypA $\mathrm{w}$ rejonie jej oddziaływania $\mathrm{z}$ białkiem kapsydu powoduje znaczne zaburzenie replikacji wirusa. Taki sam efekt uzyskano kiedy infekowano wirusem HIV-1 linię komórkową limfocytów T w których dokonano nokautu genu kodującego CypA. Kompleks Gag/CypA ma istotne znaczenie na wczesnym etapie cyklu wirusa, zanim dojdzie do odwrotnej transkrypcji jego genomu RNA. Prawdopodobnie obecność CypA jest konieczna do destabilizacji oddziaływań między białkami płaszcza w celu uwolnienia RNA. Istnieją przypuszczenia, że dołączona do białka kapsydu cyklofilina, eksponowana na jego powierzchni, może brać udział w procesie rozpoznawania limfocytów T przez wirusa. Przeciwciała skierowane na ten eksponowany region blokują przyłączanie wirusa HIV-1 do komórki [10]. Ponadto badania in vitro wykazały, że dwa inne wirusowe białka (Vpr i p6) oddziałują z CypA, jednakże ich udział w cyklu rozwojowym wirusa nie jest do końca wyjaśniony, a oddziaływanie $\mathrm{w}$ warunkach in vivo musi być potwierdzone [11]. Wykazano również, że CD147, błonowe białko limfocytów człowieka, jest głównym receptorem dla CypA powiązanej z kapsydem wirusa co może wpływać na wczesne etapy infekcji $[12,13]$.

Innym białkiem komórki gospodarza, które pełni istotne funkcje podczas infekcji wirusem HIV-1, jest Nup358. Nup358 jest nukleoporyną o masie cząsteczkowej 358 kDa $\mathrm{i}$ jest to największe, poznane dotychczas, białko posiadające domenę CBD. Oprócz domeny CBD zlokalizowanej w jego karboksylowym regionie, w Nup358 znajdują się (licząc od 
N-końca): motyw zamka leucynowego, czterokrotnie powtórzone miejsce oddziaływania z GTPazą Ran (RanBP, ang. ran binding protein) otoczone powtórzeniami reszt aminokwasowych FXFG albo FG. Tuż za pierwszą domeną RanBP znajduje się motyw ośmiu palców cynkowych typu Cys2-Cys2 [13]. Białko Nup358 jest częścią składową struktur tzw. wypustek poru jądrowego skierowanych w stronę cytoplazmatyczną. Wykazano, że białko kapsydu wirusa HIV-1 oddziałuje z domeną CBD nukleoporyny Nup358 i może mieć to wpływ na proces importu do jądra komórkowego kompleksu preintegracyjnego PIC (ang. preintegration complexes). Podobnie jak w przypadku oddziaływania CypA z poliproteiną Gag, miejscem rozpoznawanym przez Nup358 jest rejon Gly89 i Pro90 białka kapsydu [14,15]. Zakłada się, że Nup358 asystuje w transporcie genomu wirusa do poru jądrowego. $W$ procesie tym bierze również udział białko motoryczne, kinezyna KIF5B, które wspomaga relokację Nup358 z poru jądrowego i jego oddziaływanie z poliproteiną Gag. W kontakcie z Nup358, RNA wirusa uwalniany jest z kapsydu, następnie dochodzi do odwrotnej transkrypcji a po utworzeniu formy dwuniciowej, wirusowy dsDNA przedostaje się do jądra komórkowego [14, 16]. Działanie kinezyny KIF5B jest indukowane w wyniku infekcji wirusem HIV-1, natomiast mutacja genu kodującego to białko powoduje ograniczenie importu wirusowego dsDNA do jądra komórkowego.

Genom wirusa grypy zbudowany jest z cząsteczki jednoniciowego RNA. Istotną funkcję podczas infekcji odgrywa białko M1 które odpowiada za rozmontowanie kapsydu, eksport z jądra vRNP, składanie nowych cząsteczek wirusa, uruchomienie $\mathrm{w}$ kompleksie $\mathrm{z}$ caspazą- 8 procesów apoptozy oraz wydostanie się cząsteczek potomnych wirusa z zainfekowanej komórki [17]. Badania prowadzone na komórkach infekowanych wirusem „ptasiej grypy” H9N2 wykazały, że gen ChCypA kodujący cytoplazmatyczną cyklofilinę ulega w nich podwyższonej ekspresji, a jego nadekspresja prowadzi do hamowania infekcji $[18,19]$. Ptasia ChCypA oddziałując bezpośrednio z białkiem M1, blokuje replikacje wirusa i przyspiesza degradację M1 przez proteasom na drodze UPS (ang. ubiquitin proteasome system) [20].

Jak widać funkcja komórkowej cyklofiliny CypA podczas cyklu rozwojowego dwóch różnych wirusów RNA jest inna. W przypadku wirusa HIV (należący do rodziny Retroviridae) CypA funkcjonuje jako izomeraza i jest niezbędna do rozwoju wirusa, natomiast w przypadku wirusa grypy (należący do rodziny Orthomyxoviridae) CypA funkcjonuje jako inhibitor infekcji niezależnie od jej aktywności izomerazowej [19].

\section{CYKLOFILINY BAKTERYJNE}

Analiza genomów różnych bakterii wykazała obecność genów kodujących wszystkie trzy rodzaje izomeraz peptydyloprolilowych, natomiast nie $\mathrm{u}$ wszystkich badanych gatunków scharakteryzowano komplet izomeraz. W przypadku Archaebacteria jedynie u Halobacterium cutirubrum oraz Methanobacterium themoautotrophicum wykryto geny kodujące cyklofiliny natomiast u większości znaleziono geny kodujące białka FKBP [21]. Genom modelowej bakterii Gram-ujemnej Escherichia coli szczep K-12 zawiera cztery geny kodujące FKBP, trzy kodujące parwuliny oraz dwa dla cyklofilin (ppiA i ppiB), natomiast genom Bacillus subtilis (modelowa bakteria Gram-dodatnia) koduje jedną cyklofilinę (odpowiednik ppiB) i dwie parwuliny, nie stwierdzono genów kodujących białka FKBP. U bakterii E. coli izomerazy są powiązane z błoną komórkową albo mogą znajdować się we frakcji cytoplazmatycznej jak również w przestrzeni periplazmatycznej [22]. Funkcjonowanie w przestrzeni periplazmatycznej komórek E. coli wielu izomeraz (zarówno cyklofiliny jak i białka FKBP) wskazuje na to, że u bakterii Gram-ujemnych periplazma jest ważnym „przedziałem”, gdzie dochodzi do fałdowania białek, które są wydzielane z komórki $[23,24]$. Sekwencja aminokwasowa obu cyklofilin E. coli, PpiA (forma cytoplazmatyczna) i PpiB (forma znajdująca się w przestrzeni periplazmatycznej) jest identyczna na poziomie $50 \%$ natomiast $\mathrm{w}$ stosunku do innych cyklofiliny np. CypA człowieka zaledwie w 25\%. Określono strukturę przestrzenną PpiA E. coli połączonej z tripeptydem APA (sukcynylo-Ala-Pro-Ala-p-nitroanilid) przy rozdzielczości 1,8 Á [25]. Na podstawie tej analizy wywnioskowano że w oddziaływanie zaangażowane są reszty aminokwasowe umieszczone wewnątrz hydrofobowej kieszeni między dwoma przeciwbieżnymi łańcuchami tworzącymi strukturę kartki $\beta$ (Phe48, Met49, Phe107, Leu108, Tyr120 i Phe99). Struktura trzeciorzędowa PpiA E. coli w ogólnym zarysie jest podobna do CypA H. sapiens (osiem łańcuchów tworzących przeciwległe kartki $\beta$ ograniczonych z obu stron dwiema helisami a). Różnice natomiast dotyczą pętli L1, L3 i L4 oraz rejonu łączącego helisę a1 i element karki $\beta 3$. Utworzony model struktury ujawnił również zawadę przestrzenną, dodatkową (w stosunku do tożsamego rejonu w CypA $H$. sapiens) polarną resztę aminokwasową Gln89 która utrudnia PpiA E. coli oddziaływanie z CsA (około 1000 razy słabsze w porównaniu z CypA H. sapiens). Podobne właściwości wykazuje AvCypA Azotobacter vinelandii. A. vinelandi to diazotroficzne, wolnożyjące bakterie Gram-ujemne, które związany azot atmosferyczny przekształcają do amoniaku. Genom A. vinelandi koduje dwie cyklofiliny: cytoplazmatyczną AvCypA i periplazmatyczną AvCypB. Wykazano, że struktura AvCypA jest bardzo podobna do tej określonej dla PpiA E. coli.

Cyklofiliny niektórych bakterii patogennych, pełnią istotną funkcję $\mathrm{w}$ ich wirulencji. Badania na patogennych bakteriach Brucella abortus (Gram-ujemne bakterie, wywołujące chorobę zakaźną, brucelozę) wykazały podwyższony poziom ekspresji bakteryjnych genów kodujących CypA i CypB, wewnątrz zainfekowanych komórek w porównaniu $\mathrm{z}$ bakteriami hodowanymi w warunkach in vitro. Bakterie te nie wytwarzają typowych dla patogenów czynników wirulencji, takich jak egzotoksyny czy enzymy cytolityczne. Ich zdolność do przetrwania w zainfekowanej komórce wynika głównie z umiejętności unikania mechanizmów obronnych. Przygotowano podwójnego mutanta delecyjnego $\triangle c y p A B$ i stwierdzono, że ten wariant rozwija się prawidłowo podczas hodowli w warunkach sprzyjających natomiast znacznie gorzej przystosowuje się do warunków niekorzystnych takich jak: obniżenie temperatury, stres oksydacyjny, zmiany $\mathrm{pH}$ środowiska czy dodanie detergentu. Zauważono również, że mutant $\triangle c y p A B$ wykazuje mniejszą aktywność wirulencji wobec myszy (linia BALB/c) oraz niższą zdolność do przetrwania i namnażania się wewnątrz zainfekowanych komó- 
rek ludzkich (HeLa), niż szczep dziki [26]. Mimo, że mutant $\triangle c y p A B$ jest w stanie $\mathrm{z}$ powodzeniem zainfekować komórkę to nie potrafi się w niej utrzymać i przejść do formy zdolnej do replikacji. Wynika stąd, że efekt mutacji $\triangle c y p A B$ ujawnia się dopiero w warunkach stresowych jakimi są niekorzystne warunki hodowli czy konieczność przetrwania bakterii w zainfekowanej komórce broniąc się przed jej mechanizmami obronnymi. CypA B. abortus wykazuje duże podobieństwo dla typowych bakteryjnych (Gram-ujemnych) cyklofilin o lokalizacji w przestrzeni periplazmatycznej, natomiast СурB wykazuje większe podobieństwo do form eukariotycznych (obecność istotnej dla oddziaływania z CsA reszty Trp125) i znajduje się raczej w cytoplazmie bakteryjnej. Sugeruje się, że cyklofiliny B. abortus pełnią istotną funkcję na etapie połączenia się BCV (ang. Brucella-containing vacuole) z błonami siateczki śródplazmatycznej co pozwala bakteriom przejść do stadium zdolnego do replikacji.

Niektóre bakterie wydalają swoją własną cyklofilinę podczas infekcji. Komórki Mycobacterium tuberculosis produkują dwa rodzaje cyklofilin PpiA i PpiB, z czego forma A swoją strukturą bardzo przypomina CypA człowieka. Dodatkowo PpiA na aminowym końcu posiada sekwencję sygnałową umożliwiającą sekrecję białka z komórek bakterii [27]. Duże podobieństwo strukturalne między wymienionymi białkami może sugerować, że PpiA może przejąć funkcje CypA jako efektora podczas rozwoju infekcji.

U bakterii Flavobacterium johnsonii i Treponema denticola jak również u wielu pierwotniaków scharakteryzowano białka, które w swojej strukturze zawierają zarówno domenę CBD jak i FKBP, nazwano je FCBP (ang. FK506 and cyclosporin-binding protein) [28]. Wykazano, że obie domeny są funkcjonalnymi izomerazami, których aktywność jest blokowana przez specyficzne im inhibitory bez wpływu na działanie drugiej domeny.

\section{CYKLOFILINY WYSTĘPUJĄCE U PIERWOTNIAKÓW}

Najwięcej informacji dotyczących cyklofilin u Protozoa pochodzi z badań przeprowadzonych na pierwotniakach pasożytniczych. Zainteresowanie tą grupą białek wzrosło po odkryciu, że cyklosporyna (CsA) wykazuje aktywność przeciwpasożytniczą z czego mogło wynikać, że cyklofiliny pełnią istotną rolę podczas infekcji [29]. Większość izomeraz peptydyloprolylowych występujących u pierwotniaków to cyklofiliny. Pierwsze cyklofiliny scharakteryzowane u Plasmodium falciparum i Toxoplasma gondii [30]. Analiza in silico sekwencji DNA genomów niektórych pierwotniaków wykazała dużą liczbę genów kodujących różniące się strukturą domenową cyklofiliny, dla rodzaju Cryptosporidium - 9 natomiast Toxoplasma - 14. Sklonowano 11 białek z domenami CBP, które znaleziono w genomie P. falciparum. Tylko dwa ze sklonowanych białek wykazywały aktywność izomerazową wobec substratu (Ala-Leu-Pro-Phe-p-nitroanilid), natomiast wszystkie brały aktywny udział $\mathrm{w}$ fałdowaniu polipeptydów co zostało przetestowane z zastosowaniem białek modelowych $\mathrm{w}$ tego rodzaju analizach czyli syntazy cytrynianowej oraz transferazy siarkowej tiosiarczanu. Brak aktywności izomerazowej $\mathrm{u}$ większości cyklofilin $P$. falciparum wynika z braku kluczowych reszt aminokwasowych w strukturach ich domeny CBD, które są niezbędne do oddziaływania $\mathrm{z}$ potencjalnym substratem. Natomiast zachowanie ich aktywności jako czaperony związane jest prawdopodobnie z koniecznością „ratowania” białek $P$. falciparum po infekcji erytrocytów w warunkach stresowych, np. podwyższonej temperatury gospodarza. Cyklofiliny występujące $\mathrm{u} P$. falciparum tak samo jak $\mathrm{u}$ innych organizmów eukariotycznych mogą funkcjonować w różnych przedziałach komórkowych (cytoplazma, mitochondrium, jądro komórkowe) i wykazują duże zróżnicowanie pod względem struktury i wielkości (od 125 aa do 747 aa). Scharakteryzowano białka zarówno jednodomenowe (np. PfCypA, PfCypB, PfCyp23, PfCyp25) jak i wielodomenowe, które oprócz domeny CBP posiadają domeny: U-box i palec cynkowy (PfCyp72), WD40 (PfCyp87), RRM (PfCyp14). Dla większości z tych cyklofilin przewidziano lokalizację $\mathrm{w}$ jądrze komórkowym a ich kompozycja domenowa wskazuje na udział w dojrzewaniu RNA. Wykazano podwyższony poziom ekspresji genów Pfcyp19A i Pfcyp19B w stadium pierścienia pasożyta podczas jego schizogonicznego podziału w erytrocytach. Na tym etapie pasożyty są wrażliwe na działanie cyklosporyny. U T. gondi zaobserwowano ciekawy mechanizm, który wpływa na funkcjonowanie zainfekowanego organizmu. Pierwotniak wpływa na przeciwzapalną sygnalizację komórek gospodarza w taki sposób, aby zmaksymalizować mnożenie i rozprzestrzenianie się pasożytów, utrzymując jednocześnie przeżycie gospodarza [31]. T. gondi poprzez wydzielanie cyklofiliny TgCyp18 powoduje aktywację receptora chemokin CCR5 (receptor 5 chemokin typu cysteina-cysteina) w komórkach dendrytycznych i makrofagach co w konsekwencji zwiększa ekspresję interferonu (IFN) $-\gamma$, zależną od interleukiny (IL) -12. Zjawisko to jest kluczowe dla przeżycia ostrej toksoplazmozy.

U T. gondi scharakteryzowano podobnie jak u niektórych bakterii białko zawierające zarówno domenę CBP jak i FKBP (FCBP), jego dwie domeny izomerazowe są rozdzielone trzykrotnie powtórzoną domeną TRP.

\section{FUNKCJE CYKLOFILIN W KOMÓRKACH ZWIERZĘCYCH}

W poprzednich rozdziałach opisano eukariotyczne cyklofiliny funkcjonujące podczas obrony przed wirusami i bakteriami. Jednakże znaczenie tych białek oraz ich różnorodność pod względem występowania jest znacznie bardziej rozszerzona niż tylko ochrona przeciw patogenom.

Jak już wcześniej wspomniano, cyklofiliny biorą udział w modulowaniu szlaków sygnałowych, kontrolujących zarówno proliferację, jak i apoptozę limfocytów T. Pierwsze badania nad cyklofilinami prowadzono analizując zastosowanie różnych związków immunosupresyjnych w transplantologii. Wykazano wówczas, że wewnątrzkomórkowym receptorem dla cyklosporyny A (CsA) (jeden z immunocytostatyków) jest cytoplazmatyczna cyklofilina CypA. Kompleks CypA/CsA wpływa na proces aktywacji limfocytów $\mathrm{T}$ poprzez blokowanie aktywności fosfatazy kalcyneuryny.

Cyklofiliny scharakteryzowane u człowieka można podzielić na 16 grup białek różniących się strukturalnie, jednakże najbardziej liczną jest grupa CypA, która stanowi od 0,1 do $0,6 \%$ wszystkich białek występujących w komórce [32]. 
Początkowo sądzono, że CypA funkcjonuje tylko wewnątrz komórki, jednakże dzisiaj wiadomo, że może ona funkcjonować również jako zewnątrzkomórkowy przekaźnik pełniący istotną rolę w wielu jednostkach chorobowych. Cyklofilina CypA może podlegać sekrecji z komórek zwierzęcych, jako SOXF (ang. secreted oxidative stress-induced factor), pod wpływem takich bodźców jak: stres oksydacyjny, niedotlenienie czy zakażenie [33]. Sekrecja CypA stymuluje aktywację kinazy typu ERK (ang. extracellular signal-regulated kinases) i pośrednio wzrost komórek mięśni gładkich naczyń (VSMC, ang. vascular smooth muscle cell) oraz apoptozę komórek śródbłonka. Komórki VSMC wydzielają CypA poprzez pęcherzyki na drodze sekrecji z udziałem GTPazy Rho oraz miozyny II [34]. Stwierdzono podwyższony poziom ekspresji genu CypA w przebiegu takich chorób jak: tętniak aorty brzusznej, przerost serca, niedokrwienie mięśnia sercowego, choroba naczyń włosowatych czy miażdżyca tętnic. W ostatnim z wymienionych przykładów CypA stymuluje pobieranie przez komórki naczyń LDL (ang. low-density lipoprotein) wpływając na poziom receptora LDL, jednocześnie powoduje obniżenie poziomu syntazy tlenku azotu. To spostrzeżenie spowodowało, że analiza stężenia CypA stała się dobrym markerem przy diagnozowaniu niektórych chorób. Opierano się na spostrzeżeniu, że w niektórych jednostkach chorobowych zaobserwowano podwyższone stężenie CypA w surowicy krwi w porównaniu ze zdrowymi osobnikami [35]. Podobne zależności zauważono w chorobach cukrzycy typu drugiego [36].

Mówiąc o dolegliwościach, jakie dotykają człowieka nie sposób pominać choroby nowotworowe. Wiele wskazuje na to, że CypA jest kluczowym czynnikiem determinującym złośliwą transformację komórek i przerzuty niektórych komórek nowotworowych. Wykazano, że podwyższona ekspresja CypA w wielu komórkach rakowych stymuluje ich namnażanie oraz rozprzestrzenianie, blokuje również rozwój procesów apoptozy jak również powoduje odporność komórek na chemioterapię [37]. Wszystkie te spostrzeżenia spowodowały duże zainteresowanie inhibitorami cyklofilin, badania te jednak napotkały na pewne problemy związane z koniecznością rozróżnienia cyklofiliny wewnątrzkomórkowej od tej podlegającej sekrecji. Najbardziej obiecującym kierunkiem badań, jest szukanie związków wyłączających tylko i wyłącznie funkcje danej cyklofiliny [38].

Analiza wielodomenowej cyklofiliny Cyp40 wykazała, że może ona funkcjonować jako białko opiekuńcze. W regionie aminowym białka zlokalizowana jest domena CBP, natomiast w karboksylowym znajdują się trzy domeny TPR (ang. tetratricopeptide repeats). Cyp40 wchodzi w kompleksy z Hsp70 albo Hsp90 poprzez domenę TPR. Tak utworzone kompleksy asystują podczas fałdowania receptorów hormonów steroidowych, oddziałując z nimi utrzymują je $\mathrm{w}$ formie nieaktywnej. Pojawienie się hormonów steroidowych powoduje uaktywnienie receptora. Wówczas dochodzi do dokończenia fałdowania, dzięki czemu receptor nabywa zdolność oddziaływania z DNA i może funkcjonować, jako czynnik transkrypcyjny [39].

\section{CYCKLOFILINY GRZYBÓW}

Grzyby, tradycyjnie dzielimy na jednokomórkowe (drożdże) i grzyby strzępkowe. Podział ten jest jednak bardzo nieprecyzyjny, ponieważ wiele gatunków w zależności od warunków środowiskowych może występować zarówno w postaci pojedynczych komórek jak i strzępek formujących grzybnie. W komórkach Sacchaaromyces cerevisie, będącym organizmem modelowym, zidentyfikowano sekwencje kodujące: 8 cyklofilin, którym nadano oznaczenie Cpr (ang. Cyclosporin A-sensitive proline rotamase) 4 białka oddziałujące z FK506 i tylko jedną parvulinę [40].

Najwięcej doniesień na temat cyklofilin obecnych w drożdżach dotyczy białka Cpr1, które jest homologiem CypA człowieka. Cyklofilina Cpr1 S. cerevisie to białko zlokalizowane w cytoplazmie i jądrze komórkowym, zbudowane z pojedynczej domeny cyklofilinowej nadającej jej aktywność izomerazy peptydyloprolilowej [41]. Wykazano udział Cpr1 w procesie sporulacji. Sporulacja drożdży jest złożonym procesem różnicowania komórek indukowanym przez niedobór azotu i węgla. Wspomniane warunki środowiskowe aktywują skoordynowaną kaskadę zmian w ekspresji genów prowadzącą do powstania haploidalnych zarodników odpornych na niekorzystne warunki środowiska. Regulacja tego procesu zależna jest od aktywności genu IME1 (ang. inducer of meiosis) [42]. Poza regulacją opartą na oddziaływaniu czynników transkrypcyjnych z regionem promotorowym genu IME1 (czynniki MATa i MATa), kontrola jego ekspresji wynika również z modulacji dostępności chromatyny dla elementów regulujących syntezę mRNA. Jednym z elementów odpowiedzialnych za represję głównego induktora procesu sporulacji w komórkach drożdży jest kompleks Set3C, w którego skład wchodzą białka Set3, Snt1, YIL112w, Sif2, Cpr1 i dwie deacetylazy histonowe Hos2, Hst1. W regulacji ekspresji genu IME1 bierze udział jedynie deacetylaza Hos2, której brak w komórkach prowadzi do zniesienia represji genów odpowiedzialnych za inicjacje procesu mejozy i sporulacji [43]. Stwierdzono, że Cpr1 nie tylko oddziałuje z elementami kompleksu Set3C zawierającym deacetylazę Hos2 ale również bierze udział w deacetylacji histonów katalizowanej przez białko Rpd3 co wskazuje na funkcjonalne powiązania pomiędzy cyklofiliną a deacetylazami takimi jak Hos2 i Rpd3 [44]. Delecja genów kodujących białka Set3 i Hos2 wchodzących w skład kompleksu powoduje przyspieszenie procesu sporulacji co wskazuje na udział Set3C w procesie regulacji ekspresji genu IME1. Z kolei delecja genu kodującego Cpr1 powoduje spowolnienie procesu zarodnikowania jednakże nie prowadzi do jego zatrzymania, co wskazuje na to, że Cpr1 stanowi elementu niezbędnego w kontroli ekspresji genów specyficznych dla zarodnikowania. Ponad to wprowadzenie do komórki drożdży, pozbawionej sekwencji kodującej białko Cpr1, konstrukcji genowej zawierającej sekwencję kodującą cyklofilnę A z substytucją reszty argininy za resztę alaniny w 53 pozycji łańcucha białkowego, znajdującej się w obrębie miejsca aktywnego izomerazy peptydyloprolilowej, nie spowodowało przywrócenia pierwotnego poziomu sporulacji $S$. cerevisie co wskazuje na istotność aktywności izomerazowej cyklofiliny Crp1 [43]. Na podstawie powyższych zależności można przypuszczać że białko Cpr1, będące elementem kompleksu Set3C może regulować jego aktywność poprzez katalizowanie reakcji izomeryzacji, powodując zmiany konformacyjne białek kompleksu, co może wpływać na siłę jego oddziaływań z chromatyną lub innymi czynnikami [41]. 
Cpr1 drożdży S. cerevisie bierze udział w nabywaniu tolerancji na szkodliwe warunki środowiska. Wzrost ekspresji genu Cpr1 zaobserwowano w odpowiedzi na czynniki powodujące powstawanie stresu oksydacyjnego i generowanie reaktywnych form tlenu (ROS), takie jak szok cieplny, obecność nadtlenku wodoru $\left(\mathrm{H}_{2} \mathrm{O}_{2}\right)$, chlorku kadmu $\left(\mathrm{CdCl}_{2}\right)$, nadtlenek tert-butylu (t-BOOH) i chlorku kobaltu $\left(\mathrm{CoCl}_{2}\right)$. Spadek zawartości cyklofiliny A drożdży zaobserwowano pod wpływem siarczanu (VI) miedzi $\left(\mathrm{CuSO}_{4}\right)$ oraz siarczanu dodecylu sodu (SDS). Nadekspresja Cpr1 znacznie zwiększa żywotność drożdży w warunkach stresu generowanego przez wspomniane czynniki co wskazuje, że cyklofiliny mogą pełnić podobne funkcje do białek Hsp, które ulegają wzmożonej ekspresji w warunkach stresowych. Ponadto Cpr1 bierze udział w uruchomieniu mechanizmów obronnych takich jak ekspresja enzymów o aktywności oksyreduktazy np. peroksydaza treoninowa, dehydrogenaza aldehydu 3-fosfoglicerynianowa i dehydrogenaza glukozo-6-fosforanowa oraz białek opiekuńczych Hsp104, Hsp90, Hsp60 i Hsp42, których zadaniem jest utrzymanie stanów przejściowych niepoprawnie ufałdowanych białek i kontrola nad uzyskaniem przez nie struktury natywnej [45]. Ponad to wzrost ekspresji Cpr1 stwierdzono również w ekstremalnej temperaturze i w obecności chlorku sodu oraz kwasu sorbinowego. Badania mające na celu porównanie wrażliwości komórek drożdży szczepów KNU5377Y i KNU5377Y cpr1s wykazały, że delecja genu kodującego cyklofilinę Cpr1 powoduje obniżenie tolerancji na czynniki stresowe, towarzyszace procesowi fermentacji, takie jak wysoka temperatura $\left(45^{\circ} \mathrm{C}\right)$, dwutlenek wodoru (20-30 $\mathrm{mM})$, etanol $(16 \%)$, kwas siarkowy (5 mM), i kwas mlekowy $(0,4-0,8 \%)$. Zależności te wskazują na rolę cyklofilin w odpowiedzi na stresy środowiskowe powodowane różnymi czynnikami. Przyczyną tego może być zdolność cyklofilin do pełnienia podobnych funkcji jak białka opiekuńcze Hsp oraz często obserwowane współdziałanie pomiędzy czaperonami a cyklofilinami. Oddziaływanie to umożliwia utrzymanie stanów przejściowych w trakcie fałdowania białek co w warunkach stresowych umożliwia uzyskanie konfiguracji natywnej [46]

Białka posiadające zdolność do katalizowania reakcji izomeryzacji wiązań peptydowych a szczególnie homolog cyklofiliny A (Cyp1) pełnią różnego rodzaju funkcję w wirulencji grzybów i procesie infekcji. U Magnaporthe oryzae Cyp1 reguluje generowanie wysokiego turgoru w komórkach appressorium, biosyntezę lipidów i rozwój spor. Rośliny infekowane przez mutanty $M$. oryzae pozbawione genu cyp 1 wykazywały mniejsze nasilenie zmian chorobowych $\mathrm{w}$ porównaniu $\mathrm{z}$ infekcją przez typ dziki. Ponadto grzyby $\mathrm{z}$ tego gatunku pozbawione genu cyp1 charakteryzowały się osłabioną zdolnością do penetrowania warstwy kutykuli rośliny-gospodarza. Mutanty $\Delta$ cyp1 wykazują znacznie spowolnione formowanie konidiów w porównaniu do typu dzikiego. Podobnie w przypadku B. cinerea wyciszenie bcp1, będącego homologiem cyp1 $M$. oryzae, powoduje osłabienie objawów chorobowych. Jednak nie wpływa na rozwój grzybni i formowanie oraz dojrzewanie konidiów [47].

Zdecydowana większość badań nad funkcją cyklofilin u grzybów wskazuje na ich szczególne znaczenie w odpowie- dzi na stresy abiotyczne, szczególnie czynniki powodujące stres oksydacyjny. Stwierdzono również ich udział w regulacji procesu mejozy I sporulacji oraz replikacji RNA wirusów. Ponadto cyklofiliny stanowią ważny element warunkujący zdolność grzybów patogennnych do infekowania gospodarzy. U wielu gatunków zaobserwowano spadek wirulencji na skutek delecji lub wyciszenia genów kodujących cyklofiliny. Brak badanych białek nie wpływa jednak na parametry wzrostowe grzybów strzępkowych jak również, w większości przypadków, na formowanie, wzrost $\mathrm{i}$ rozwój spor.

\section{FUNKCJE CYKLOFILIN W KOMÓRKACH ROŚLINNYCH}

Znaczna część białek biorących udział w odpowiedzi komórki roślinnej na infekcję patogenem oraz te które ulegają ekspresji podczas rozwoju układu symbiotycznego charakteryzuje się dużą zawartością reszt proliny. Rośliny charakteryzują się dużą różnorodnością form białek posiadających domenę cyklofilinową. W genomie Arabidopsis thaliana scharakteryzowano 35 genów kodujących białka z domeną CBD, u Oryza sativa 28, u Lotu japonicus 14 i aż 62 u Glycine max.

Najlepiej poznaną pod względem funkcji jest cyklofilina TLP40 szpinaku (odpowiednik u A. thaliana AtCyp38), która zlokalizowana jest $\mathrm{w}$ tylakoidach chloroplastów i bierze udział w biogenezie plastydów. Wykazano, że białko TLP40 jest niezbędne do składania i dojrzewania podjednostek fotosystemu PSII [48]. Mutanty insercyjne A. thaliana z uszkodzonym genem AtCyp38 charakteryzują się ograniczonym wzrostem, oraz zmniejszoną zawartość chlorofilu w suchej masie w porównaniu do dzikiej formy. Analiza proteomiczna błon tylakoidalnych, wskazały na uszkodzenie PSII. Inna cyklofilina zlokalizowana $\mathrm{w}$ stromie chloroplastów AtCyp20-3 (nazywana również u A. thaliana ROC4) wiązana jest z odpowiedzią na stres oksydacyjny i osmotyczny. Przypuszcza się, że białko to w warunkach stresowych może oddziaływać z chloroplastową chloroplastowymi białkami peroksyredoksyną oraz tioredoksyną Trx-m. Cyklofilina AtCyp20-3 w swojej strukturze ma cztery reszty cysteiny (Cys54-Cys171 i Cys129-Cys176), które w warunkach utleniających tworzę mostki disiarczkowe. Ukierunkowane mutacje punktowe, zmieniające reszty Cys na Ser, spowodowały zmiany w konformacji białka jak również znaczne zmniejszenie aktywności izomerazowej [49].

Cyklofiliną, która uczestniczy w transporcie jądrowym u roślin jest Cyp40. Badając proces dojrzewania miRNA u A. thaliana, scharakteryzowano kompleks składający się z Cyp40, Hsp90, dupleksu RNA i AGO1. Oddziaływanie to jest niezbędne do zbudowania kompleksu RISC ( $\mathrm{z}$ ang. RNA induced silencing complexes), lecz ma charakter przejściowy, ponieważ dojrzałe formy RISC nie są połączone z Cyp40. Domena cyklofilinowa białka Cyp40 pełni istotną funkcję w składaniu kompleksu, ponieważ jej usunięcie powoduje współoczyszczanie Hsp90 z AGO1, jednakże bez dupleksu RNA [50].

Białko AtCyp59 jest przedstawicielem cyklofilin wielodomenowych u A. thaliana. Oprócz domeny CBP umieszczonej na końcu aminowym, białko to ma motywy RRM oraz palca cynkowego, natomiast koniec karboksylowy jest bogaty $\mathrm{w}$ 
powtórzenia reszt aminokwasowych RS/RD [51]. Podobne białka występują $\mathrm{u}$ innych organizmów (np. Rct u Schizosaccharomyces pombe), jednakże motyw palca cynkowego jest charakterystyczny tylko dla roślin. AtCyp59 ma lokalizację jądrową i oddziałuje z domeną CTD największej podjednostki polimerazy RNA II oraz jądrowymi białkami SR (ang. serine-arginine rich proteins) co wskazuje na udział tego białka $\mathrm{w}$ procesie dojrzewania pre-mRNA. Za pomocą domeny RRM AtCyp59 może oddziaływać z RNA, natomiast domena bogata w powtórzenia RS/RD odpowiedzialna jest za oddziaływanie z białkami SR. Za pomocą metody SELEX (ang. systematic evolution of ligands by expotential enrichment) określono motyw RNA G[U/C]N[G/A]CC[A/G], z którym preferencyjnie oddziałuje AtCyp59 [52]. Uzyskany wynik zweryfikowano in vitro za pomoca techniki EMSA (ang. electrophoretic mobility shift assay) oraz in vivo poprzez immunoprecypitację, stosując 17 wariantów sekwencji zgodnej.

Kolejnym białkiem o lokalizacji jądrowej Cyp71 $A$. thaliana, która bierze udział $\mathrm{w}$ regulacji na poziomie aktywacji chromatyny. Aminowy region AtCyp71 zbudowany jest 4 powtórzeń motywu WD40, natomiast na karboksylowym końcu znajduje się domena CBP. Mutanty insercyjne $A$. thaliana z uszkodzonym genem Cyp 71, wykazują istotne zmiany fenotypowe (zakłócenie rozwoju organów bocznych, deformacja rozety) w stosunku do formy dzikiej. Zmiany morfologiczne mutanta wskazywały na pośrednie upośledzenie funkcjonalności genów regulujących apikalny rozwój roślin. Poprzez immunoprecypitację chromatyny (ChIP, ang. chromatin immunoprecipitation) wykazano, że AtCyp71 oddziałuje z histonami H3 w regionach genów KNAT1 i STM (kodujących czynniki transkrypcyjne kontrolujące rozwój organów bocznych). Metylacja Lys27 histonów H3 (H3K27) w regionach genów KNAT1 i STM powoduje ich wyciszanie w organach bocznych roślin [53]. Uważa się, że AtCyp71 poprzez oddziaływanie z histonami H3 wpływa na ich potranslacyjną modyfikację. W mutancie cyp71-1 oba geny zostały zaktywowane, co zmieniło przebieg wzrostu rośliny, wskazując na to, że metylacja histonu H3 w pozycji Lys27 została zakłócona.

Ekspresja genów kodujących poszczególne typy cyklofilin u roślin jest zróżnicowana. Niektóre cyklofiliny ulegają ekspresji w sposób konstytutywny dla innych można wykazać podwyższony poziom mRNA w warunkach stresu biotycznego bądź abiotycznego, jeszcze inne ulegają ekspresji tylko w określonych tkankach [54]. Zaobserwowano podwyższony poziom mRNA dla CypA w tkankach szybko rosnących i rozwijających się. Ekspresja CypA u Solanum tuberosum wzmaga się w wyniku skaleczenia czy infekcji grzybowej, natomiast $\mathrm{u}$ fasoli reaguje na obniżoną temperaturę czy działanie na rośliny solami metali ciężkich [55].

U A. thaliana scharakteryzowano dwie cyklofiliny: cytoplazmatyczną AtCyp19 oraz jądrową AtCyp57, których ekspresja jest indukowana $\mathrm{w}$ wyniku infekcji Pseudomonas syringae. Mutanty atcyp 19 oraz atcyp57 z uszkodzonymi genami kodującymi wyżej wymienione białka, wykazują podwyższoną podatność na infekcję $P$. syringae, natomiast nadekspresja AtCyp19 powoduje zwiększenie odporności na infekcję [56]. Nadekspresja AtCyp19 prowadzi do nagromadzenia się reaktywnych form tlenu, co w konsekwencji po- woduje modyfikację ściany komórkowej indukcję produkcji kwasu salicylowego oraz ekspresję genów w odpowiedzi na atak patogena uruchamiając kaskadę kinazy MAP (ang. mitogen-activated protein kinase). Natomiast nadekspresja AtCyp57 powoduje nagromadzenie w ścianie komórkowej kalozy, czyniąc ją mniej przepuszczalną dla bakteryjnego patogenu.

Innym białkiem, które uczestniczy w odpowiedzi obronnej na infekcję $P$. syringae jest AtCyp18-3 (ROC1). Białko to oddziałuje z proteazą cysteinową AvrRpt2, która należy do białek efektorowych bakterii [57]. Białka efektorowe są wydzielane przez bakterie bezpośrednio do komórki gospodarza, w wyniku czego rośliny produkują tzw. białka odporności R (ang. plant resistance protein), które indukują odpowiedź obronną komórki. Proteaza AvrRpt2 w formie nieaktywnej, transportowana jest do zainfekowanej komórki po czym podlega potranslacyjnej modyfikacji tj. izomeryzacji wiązań peptydowych między Gly-Pro z udziałem cyklofiliny AtCYP18-3. W strukturze AvrRpt2 scharakteryzowano czterokrotnie powtórzoną sekwencję Gly-Pro-X-Lys (X oznacza dowolną resztę aminokwasową), z którą oddziałuje AtCyp18-3. Zakłada się, że w komórce bakteryjnej, nieufałdowana i nieaktywna forma AvrRpt2 zawiera wiązania peptydowe Gly-Pro w konfiguracji trans, dopiero po przejściu do komórki gospodarza w asyście cyklofiliny AtCyp18-3 część z nich przechodzi do konfiguracji cis. Po odpowiednim ufałdowaniu dochodzi do autoodcięcia aminowego regionu AvrRpt2 (pomiędzy Gly71 i Gly72), co uaktywnia aktywność proteazową AvrRpt2 i umożliwia proteolityczne cięcie białka RIN4, które poprzez oddziaływanie z białkiem typu R (RPS2) blokuje jego aktywność. Konsekwencją usunięcia RIN4 jest uwolnienie RPS2 i rozpoczęcie odpowiedzi obronnej rośliny.

Ponadto wiadomo, że AtCYP18-3 oddziałuje z białkiem VirD2 Agrobacterium tumefaciens, co umożliwia wprowadzenie do jądra komórki roślinnej oraz wbudowanie do jej genomu sekwencji T-DNA [58].

\section{PODSUMOWANIE}

Mimo, że od odkrycia zjawiska przyspieszania izomeryzacji wiązań Xaa-Pro przez izomerazy peptydyloprolilowe, minęło ponad 30 lat niewiele wiadomo o specyficzności substratowej oraz funkcji in vivo ich poszczególnych form. Cyklofiliny reprezentowane są $\mathrm{w}$ analizowanych organizmach przez wiele form zarówno jedno- jak i wielodomenowych. Dużym wyzwaniem dla badaczy jest przybliżenie funkcji i znaczenia poszczególnych form cyklofilin zarówno w warunkach optymalnych jak i stresowych czy patogennych.

\section{PIŚMIENNICTWO}

1. Stewart DE, Sarkar A, Wampler JE (1990) Occurrence and role of cis peptide bonds in protein structures. J Mol Biol 214: 253-260

2. Guan RJ, Xiang Y, He XL, Wang CG, Wang M, Zhang Y, Sundberg EJ, Wang DC (2004) Structural mechanism governing cis and trans isomeric states and an intramolecular switch for cis/trans isomerization of a non-proline peptide bond observed in crystal structures of scorpion toxins. J Mol Biol 341: 1189-1204

3. Wang P, Heitman J (2005) The cyclophilins. Genome Biology 6: 226231 
4. Liu J, Farmer JDJr, Lane WS, Friedman J, Weissman I, Schreiber SL (1991) Calcineurin is a common target of cyclophilin-cyclosporin A and FKBP-FK506 complexes. Cell 23: 807-815

5. Fischer G, Schmid FX (1990) The mechanism of protein folding. Implications of in vitro refolding models for de novo protein folding and translocation in the cell. Biochemistry 29: 2205-2212

6. Fischer G, Tradler T, Zarnt T (1998) The mode of action of peptidyl prolyl cis/trans isomerases in vivo: binding vs. catalysis. FEBS 426: $17-$ 20

7. Hsin JP, Manley JL (2012) The RNA polymerase II CTD coordinates transcription and RNA processing. Genes Dev 26: 2119-2137

8. Luban J, Bossolt KL, Franke EK, Kalpana GV, Goff SP (1993) Human immunodeficiency virus type 1 Gag protein binds to cyclophilins A and B. Cell 73: 1067-1078

9. Braaten D, Luban J (2001) Cyclophilin A regulates HIV-1 infectivity, as demonstrated by gene targeting in human T cells. EMBO J 20: 13001309

10. Solbak SM, Reksten TR, Röder R, Wray V, Horvli O, Raae AJ, Henklein P, Henklein P, Fossen T (2012) HIV-1 p6-Another viral interaction partner to the host cellular protein cyclophilin A. Biochim Biophys Acta 1824: 667-678

11. Damsker JM, Bukrinsky MI, Constant SL (2007) Preferential chemotaxis of activated human CD4+ T cells by extracellular cyclophilin A. J Leukoc Biol 82: 613-618

12. Yurchenko V, Constant S, Bukrinsky M (2006) Dealing with the family: CD147 interactions with cyclophilins. Immunology 117: 301-309

13. Brass AL, Dykxhoorn DM, Benita Y, Yan N, Engelman A, Xavier RJ, Lieberman J, Elledge SJ (2008) Identification of host proteins required for HIV infection through a functional genomic screen. Science 319: 921-926

14. Schaller T, Ocwieja KE, Rasaiyaah J, Price AJ, Brady TL, Roth SL, Hué S, Fletcher AJ, Lee K, KewalRamani VN, Noursadeghi M, Jenner RG, James LC, Bushman FD, Towers GJ. (2011) HIV-1 capsid-cyclophilin interactions determine nuclear import pathway, integration targeting and replication efficiency. PLoS Pathog 7: e1002439. pmid:22174692

15. Bichel K, Price AJ, Schaller T, Towers GJ, Freund SM, et al. (2013) HIV1 capsid undergoes coupled binding and isomerization by the nuclear pore protein NUP358. Retrovirology 10: 81-92

16. Dharan A, Talley S, Tripathi A, Mamede Ji, Majetschak M, Hope TJ, Campbell EM (2016) KIF5B and Nup358 cooperatively mediate the nuclear import of HIV-1 during infection. PLOS Pathogens 21, doi:10.1371/journal.ppat.1005700

17. Liu X, Zhao Z, Xu C, Sun L, Chen J, Zhang L, Liu W (2012) Cyclophilin A restricts influenza A virus replication through degradation of the M1 protein. PLOS One 7: e31063

18. Liu N, Song W, Wang P, Lee K, Chan W, Chen H, Cai Z (2008) Proteomics analysis of differential expression of cellular proteins in response to avian H9N2 virus infection in human cells. Proteomics 8: 1851-1858

19. Liu X, Sun L, Yu M, Wang Z, Xu C, Xue Q, Zhang K, Ye X, Kitamura Y, Liu W (2009) Cyclophilin A interacts with influenza A virus M1 protein and impairs the early stage of the viral replication. Cell Microbiol 11: 730-741

20. Xu C, Meng S, Liu X, Sun L, Liu W (2010) Chicken cyclophilin A is an inhibitory factor to influenza virus replication. Virol J 7: 372-382

21. Nagashima K, Mitsuhashi S, Kamino K, Maruyama T (1994) Cyclosporin A sensitive A sensitive peptidyl prolyl cis-trans isomerase in a halophilic archaeum, Halobacterium cutirubrum. Biochem Biophys Res Commun 198: 466-472

22. Hayano T, Takahashi N, Kato S, Maki N, Suzuki M (1991) Two distinct forms of peptidylprolyl-cis-trans-isomerase are expressed separately in periplasmic and cytoplasmic compartments of Escherichia coli cells. Biochemistry 30: 3041-3048

23. Ramm K, Plückthun A (2001) High enzymatic activity and chaperone function are mechanistically related features of the dimeric E. coli peptidyl-prolyl-isomerase FkpA. J Mol Biol 310: 485-498
24. Hullmann J, Patzer SI, Römer C, Hantke K, Braun V (2008) Periplasmic chaperone FkpA is essential for imported colicin M toxicity. Mol Microbiol 69: 926-937

25. Konno M, Ito M, Hayano T, Takahashi N (1996) The substrate-binding site in Escherichia coli cyclophilin A preferably recognizes a cis-proline isomer or a highly distorted form of the trans isomer. J Mol Biol 256: 897-908

26. Roset MS, García Fernández L, DelVecchio VG, Briones G (2013) Intracellularly Induced cyclophilins play an important role in stress adaptation and virulence of Brucella abortus, Infect Immun 2: 521-530

27. Bhaduri A, Misra R, Maji A, Bhetaria P, Mishra S, Arora G, Singh LK, Dhasmana N, Dubey N, Virdi JS, Singh Y (2014) Mycobacterium tuberculosis cyclophilin A uses novel signal sequence for secretion and mimics eukaryotic cyclophilins for interaction with protein repertoire. PLoS One 4: e88090

28. Adams B, Musiyenko A, Kumar R, Barik S (2005) A novel class of dual-family immunophilins. J Biol Chem 280: 24308-24314

29. Bell A, Roberts HC, Chappell LH (1996) The antiparasite effects of cyclosporin A: possible drug targets and clinical applications. Gen Pharmacol 27: 963-971

30. Marín-Menéndez A, Monaghan P, Bell A (2012) A family of cyclophilin-like molecular chaperones in Plasmodium falciparum Molecular \& Biochemical Parasitology 184: 44-47

31. Denkers EY (2003) From cells to signaling cascades: manipulation of innate immunity by Toxoplasma gondii. FEMS Immunol Med Microbiol 39: 193-203

32. Nigro P, Pompilio G, Capogrossi MC (2013) Cyclophilin A: a key player for human disease. Cell Death Disease 4: e888

33. Seko Y, Fujimura T, Taka H, Mineki R, Murayama K, Nagai R (2004) Hypoxia followed by reoxygenation induces secretion of cyclophilin A from cultured rat cardiac myocytes. Biochem Biophys Res Commun 317: 162-168

34. Suzuki J, Jin ZG, Meoli DF, Matoba T, Berk BC (2006) Cyclophilin A is secreted by a vesicular pathway in vascular smooth muscle cells. Circ Res 98: 811-817

35. Satoh K, Fukumoto Y, Sugimura K, Miura Y, Aoki T, Nochioka K, Tatebe S, Miyamichi-Yamamoto S, Shimizu T, Osaki S, Takagi Y, Tsuburaya R, Ito Y, Matsumoto Y, Nakayama M, Takeda M, Takahashi J, Ito K, Yasuda S, Shimokawa H (2013) Plasma cyclophilin A is a novel biomarker for coronary artery disease. Circ J 77: 447-455

36. Ramachandran S, Venugopal A, Sathisha K, Reshmi G, Charles S, Divya G, Chandran NS, Mullassari A, Pillai MR, Kartha CC (2012) Proteomic profiling of high glucose primed monocytes identifies cyclophilin A as a potential secretory marker of inflammation in type 2 diabetes. Proteomics 12: 2808-2821

37. Choi KJ, Piao YJ, Lim MJ, Kim JH, Ha J, Choe W, Kim SS (2007) Overexpressed cyclophilin $\mathrm{A}$ in cancer cells renders resistance to hypoxiaand cisplatin-induced cell death. Cancer Res 67: 3654-3662

38. Flisiak F, Feinman SV, Jablkowski M, Horban A, Kryczka W, Pawlowska M, Heathcote JE, Mazzella G, Vandelli C, Métral VN, Grosgurin P, Liz JS, Scalfaro P, Porchet H, Crabbé R (2009) The cyclophilin inhibitor Debio 025 combined with PEG IFNalpha2a significantly reduces viral load in treatment-naive hepatitis C patients. Hepatology 49: 1460-1468

39. Carrello A, Allan RK, Morgan SL, Owen BA, Mok D, Ward BK, Minchin RF, Toft DO, Ratajczak T (2004) Interaction of the Hsp90 cochaperone cyclophilin 40 with Hsc70. Cell Stress Chaperones 9: 167-181

40. Arevalo-Rodriguez M, Wu X, Hanes SD, Heitman J (2004) Prolyl isomerases in yeast. Front Biosci 9: 2420-2446

41. Arevalo-Rodriguez M, Heitman J (2005) Cyclophilin A is localized to the nucleus and controls meiosis in Saccharomyces cerevisiae. Eukaryot Cell 4: 17-29

42. Vershon AK, Pierce M (2000) Transcriptional regulation of meiosis in yeast. Current opinion in cell biology 12: 334-339

43. Pijnappel WW, Schaft D, Roguev A, Shevchenko A, Tekotte H, Wilm M, Rigaut G, Seraphin B, Aasland R, Stewart AF (2001) The Saccharomyces cerevisiae SET3 complex includes two histone deacetylases, 
Hos2 and Hst1, and is a meiotic-specific repressor of the sporulation gene program. Genes Dev 15: 2991-3004

44. Arevalo-Rodriguez M, Cardenas ME, Wu X, Hanes SD, Heitman J (2000) Cyclophilin A and Ess1 interact with and regulate silencing by the Sin3-Rpd3 histone deacetylase. EMBO J 19: 3739-3749

45. Kim IS, Kim HY, Shin SY, Kim YS, Lee DH, Park KM, Yoon HS (2010) A cyclophilin A CPR1 overexpression enhances stress acquisition in Saccharomyces cerevisiae. Molecules and cells 29: 567-574

46. Kim IS, Yun HS, Park IS, Sohn HY, Iwahashi H, Jin N (2006) A knockout strain of CPR1 induced during fermentation of Saccharomyces cerevisiae KNU5377 is susceptible to various types of stress. Journal of bioscience and bioengineering 102: 288-296

47. Viaud MC, Balhadere PV, Talbot NJ (2002) A Magnaporthe grisea cyclophilin acts as a virulence determinant during plant infection. Plant Cell 14: 917-930

48. Fu A, He Z, Cho HS, Lima A, Buchanan BB, Luan S (2007) A chloroplast cyclophilin functions in the assembly and maintenance of photosystem II in Arabidopsis thaliana. Proc Natl Acad Sci USA 104: 15947-15952

49. Laxa M, König J, Dietz KJ, Kandlbinder A (2007) Role of the cysteine residues in Arabidopsis thaliana cyclophilin CYP20-3 in peptidyl-prolyl cis-trans isomerase and redox-related functions. Biochem J 401: 287297

50. Iki T, Yoshikawa M, Meshi T, Ishikawa M (2012) Cyclophilin 40 facilitates HSP90-mediated RISC assembly in plants. EMBO J 31: 267-278

51. Gullerova M, Barta A, Lorković ZJ (2006) AtCyp59 is a multidomain cyclophilin from Arabidopsis thaliana that interacts with SR proteins and the C-terminal domain of the RNA polymerase II. RNA 12: 631643

52. Bannikova O, Zywicki M, Marquez Y, Skrahina T, Kalyna M, Barta A (2013) Identification of RNA targets for the nuclear multidomain cyclophilin atCyp59 and their effect on PPIase activity. Nucleic Acids Res 41: 1783-1796

53. Schubert D, Primavesi L, Bishopp A, Roberts G, Doonan J, Jenuwein T, Goodrich J (2006) Silencing by plant polycomb group genes requires dispersed trimethylation of histone $\mathrm{H} 3$ at lysine 27. EMBO J 25: 46384649

54. Chou IT, Gasser CS, (1997) Characterization of the cyclophilin gene family of Arabidopsis thaliana and phylogenetic analysis of known cyclophilin proteins. Plant Mol Biol 35: 873-892

55. Nuc K, Nuc P, Slomski R (2001) Yellow lupine cyclophilin transcripts are highly accumulated in the nodule meristem zone. Molecular Plant-microbe Interactions 14: 1384-1394

56. Pogorelko GV, Mokryakova M, Fursova OV, Abdeeva I, Piruzian ES, Bruskin SA (2014) Characterization of three Arabidopsis thaliana immunophilin genes involved in the plant defense response against $P$ seudomonas syringae. Gene 538 : $12-22$

57. Coaker G, Falick A, Staskawicz B (2005) Activation of a Phytopathogenic Bacterial Effector Protein by a Eukaryotic Cyclophilin. Science 308: 548-550

58. Deng W, Chen L, Wood DW, Metcalfe T, Liang X, Gordon MP, Comai L, Nester EW (1998) Agrobacterium VirD2 protein interacts with plant host cyclophilins Proc Natl Acad Sci USA 95: 7040-7045

\section{Cyclophilins - proteins with many functions}

\section{Przemysław Olejnik, Katarzyna Nuc}

Poznań University of Life Sciences, Department of Bochemistry and Biotechnology, 60-632 Poznań, Poland

e-mail: ktnuc@up.poznan.pl

Key words: cyclophilins, protein folding, peptidylpro;yl isomerases

\section{ABSTRACT}

Cyclophilins together with FK-506-binding proteins and parvulins, belong to a group of proteins that have peptidyl-prolyl cis-trans isomerase activity. They also belong to proteins that are collectively known as immunophilins. Cyclophilins are found in all cells of all organisms studied, in both prokaryotes and eukaryotes. The first member of the cyclophilins to be identified in mammals, cyclophilin A, is the major cellular target for the immunosuppressive drug cyclosporin A. This review discusses recently available data about proteins with cyclophilin domain (CBD). Recent studies have implicated a diverse array of additional cellular functions for cyclophilins, including roles as chaperones and in cell signalling as well as in several human diseases. 